\title{
A Preliminary Study on Factors That Lead Muslim Kedayan to Continue Performing the Syncretic Culture
}

\author{
Ros Aiza Mohd Mokhtar and Che Zarrina Sa’ari
}

\begin{abstract}
Syncretism is a controversial terminology that invites discussion of whether the term should be retained or banned. Agreeing with the views of scholars who aim this terminology to be remained in the repertory, authors will discuss syncretism between Islam and local culture of Kedayan people in Sabah, Malaysia. This paper will focus on the factors that influence the intention of these people to perform their local culture that is associated with syncretism. The questionnaire consists of 70 variables were distributed to 40 respondents. The result of study revealed that Kedayan people have high tendency to continue their local culture which is not included in the teaching of their official religion, Islam. Moreover, there is a statistical significant difference between the individual attitude towards the local culture and their level of education. In addition, the results revealed high correlation between attitudes towards behavior, subjective norms and perceived behavioral control with their intention to continue performing their local culture.
\end{abstract}

Index Terms-Kedayan, local culture, Islam, syncretism.

\section{INTRODUCTION}

This paper will begin with a brief explanation on the concept of syncretism and scholars' views on it either positively or negatively. Definitely, this term has a very wide meaning and develops many forms such as fusion between gods or goddess, fusion between two or more religions, fusion between religion and philosophy etc. Thus, this paper will discuss the syncretism between the official religion of a particular community named Kedayan with their local culture. In order to explore the reasons why Kedayan people are interested in continuing performing their local culture which has always been associated with syncretism, several questions have to be answered. Therefore a set questionnaire was constructed, distributed and analyzed as will be discussed in the content.

\section{SYNCRETISM}

Syncretism is derived from the Greek word synkretizein, which means to link, combine and consolidate [1]. The term was first introduced by the Greek moralist and biographer Plutarch (16-120 AD) who reputed the term 'syncretism' to

Manuscript received July 20, 2013; revised October 27, 2013. This work is supported by Malaysia Ministry of Higher Education under $\mathrm{PhD}$ scholarship and the University of Malaya under Postgraduate Research Grant PG028-2012B. A Preliminary Study on Factors that Lead Muslim Kedayan to Continue Performing the Syncretic Culture.

The authors are with the Academy of Islamic Studies, University of Malaya, Jln Pantai Baru, Kuala Lumpur, Malaysia (e-mail: rosaizamokhtar@yahoo.com.my, zarrina@um.edu.my). denote the phenomenon of how different Cretan tribes became unified when faced with external threats to their survival [2]. The concept of syncretism was widely practiced during Greek paganism where religion, philosophy, culture and beliefs were established by merging the elements among themselves, particularly in the second century AD during Hellenistic [3]. Syncretism in that era involved alliance of the gods in various forms such as parallelism, amalgam and eclipse [4].

Religious situation in Rome was also diverse, complex and syncretistic [5]. Among the high expression of the Roman syncretism was the marriage of Roman god, Mercury with the Celtic goddess, Rosmerta which implied sharing religion between Roman and Celtic [6]. Syncretism of the modern era began in the day of Englightment particulary by Denis Diderot (1713-1784) who wrote Eclecticism and syncretiste, henotiques ou concillateurs. In his article he depicted syncretism as parallelism in a variety of sources [7]. Earlier, in the 17th century, George Calisen Calixtus attempted a rapprochement with Protestant and Catholic denominations [8]. Syncretism later employed negatively to refer to a contamination of one religion by another [9]. Robert Baird is among the scholars who wanted to remove the terminology from the study of religious history. He argued by explaining something as syncretistic in religious history is like not explaining something [10].

Inculturation terminology later was suggested to replace syncretism which would bring a more positive connotation [11]. Some prefer using hybridity rather than syncretism [12] [13], whereas some put demarcation between syncretism and anti-syncretism [14]. Some scholars also suggest steps with a new definition to syncretism because of theology, culture and missionary interest [15]. Martin viewed the understanding of syncretism as a neutral description of religious phenomena as the current academic alternative to its comparative practice. [16]. There are more positive definitions offered such as by Colpe (1987). Colpe explained that "syncretistic religions" as "the high points of syncretic processes" [17]. Michael Pye in his later work discusses the difference between syncretism and synthesis, and then summed syncretism as "the conclusion to a process is thereby completed" [18]. Thus, it is not surprised nowadays that syncretism is a phenomenon that is no more or less pejorative in nature, as there was a study that reveled Jewish teenagers as more syncretic compared to others and most of them believe that there is no problem if one practice syncretism [19].

Authors personally view that this terminology should be maintained even if it brings a negative connotation. At the same time, agree with the statement of syncretism is a process. Therefore, it is important concept for discussion in religious context, in order to evaluate the doctrines and practices of a 
particular religion. However, in this limited discussion, the authors only manage to explore the process of syncretism by looking at factors that lead people to continue their traditional practices prior to embracing a particular religion. The selected people in this study are called Kedayan who embrace Islam. Specifically, category of syncretism discussed here is syncretism between Islam and local culture.

\section{KEDAYAN}

Sipitang was selected as a location for this study because it is in the heartland of the Kedayan in Sabah, Malaysia [20]. In summary, Kedayan has been defined in Dewan Dictionary, as 'escort' or 'slave' [21]. It is associated with the life of the community as an escort king in the feudal era. The word "Kedayan" is supposed to be derived from the Malay word Kodi (meaning a score). The followers of any great native prince were known as Kodi-an [22]. There are ten different spellings of the word which so far have been spelled 'Kedayan' from different sources. Among them are Kadaian, Kadian [23]. Kedayan ethnic originated from Java whom brought by Sultan Bolkiah (Fifth Sultan of Brunei). The early history of their coming to Brunei associated with cockfighting event between Java Prince and Sultan of Brunei. Therefore, the word "Kedayan" initially refers to a job as an escort to the king. When their numbers increased, they began to form Kedayan ethnic [24].

As part of Sarawak and Sabah formerly under the rule of Brunei, Kedayan the ethnic also inhabited Sarawak and Sabah. The population of Kedayan in Borneo would be in the region of around 240,000 [25]. Kedayan people who live as farmers adopt certain paddy cultivation to ensure getting a good crop [26], [27]. In addition to planting rice, they also catch fish where certain rituals were practiced [28], [29]. The famous celebration for Kedayan people is the annual festival (Makan Tahun), which they held as soon as the harvest is completed [30], [33]. Among the local culture that is associated with syncretism among Kedayan people in Sipitang, Sabah are Langir ritual bath (mandi langir), incantations for healing purpose, ritual before building the house, hunting tips and incantations, cleaning the graves in the month of Shaaban and a variety of mourn feast.

\section{OBJECTIVES}

The specific objectives of this paper are to:

1) Identify the highest propensity of syncretic practices among Kedayan people.

2) Compare the attitudes and intentions towards syncretic practices with the different level of education among them.

3) Find out the relationship between attitudes, subjective norms and perceived behavioral control with their intentions to continue their syncretistic practices.

\section{HYPOTHESIS}

The specific hypothesis of this paper are:

1) There is a significant difference between education levels and individual attitudes towards their syncretic practices.

2) There is a correlation between attitudes, subjective norms and perceived behavioral control with the intentions of this community to perform their syncretic tradition.

\section{Methodology}

This paper discusses parts of findings of the authors' research regarding syncretism among Kedayan people. For the purpose of this paper, the survey method using questionnaires is employed as an instrument. The instrument is a self-constructed questionnaire based on the theory of Planned Behavior by Ajzen, Icek. According to the theory, we should be able to predict the performance of a behavior from intentions to performing the behavior and from behavioral control. Intention, in turn should be predictable from attitude towards the behavior, subjective norms and perceived behavioral control [34]. Guided by this theory, the researcher constructs a set of questionnaire consisting of 5 parts which are respondent demography, attitudes towards behavior, subjective norms, perceived behavioral control and behavioral intentions.

As a pilot study, questionnaires were distributed to 40 respondents. A total of $32(80 \%)$ respondents returned the questionnaires. Reliability tests were carried out to test the internal consistency of the respective scales. The scales for all variables are very reliable as all Cronbach's Alpha value exceeds 0.9 .

The data was statistically analyzed using Statistical Package for Social Sciences (SPSS). To ensure corresponding analysis are done, normality test using Shapiro Wilk was carried out. The values for all variables are below 0.05. Therefore, Kruskal-Wallis and Spearman Rank Correlation tests were carried out to test the hypothesis consistent with the non-parametric data that is obtained [35]. Scales used in this study is 1-5 (strongly disagree-strongly agree). Thus, it is considered that respondents agree with the statement when they chose scales 3-5.

\section{FINDINGS AND DISCUSSION}

\section{A. Respondent Profile}

For respondent's profile, $16(50 \%)$ of them were male, while another $16(50 \%)$ of them were female. Their age consists of four categories which are $17(53.1 \%)$ of them are 20-39 years old, 13 (40.6\%) of them are 40-59 years old, 1 $(3.1 \%)$ of them is 19 and below years old and the other one $(3.1 \%)$ of respondents is 60-79 years old. Under the employment category, $10(31.2 \%)$ of the respondents work for the government, $3(9.4 \%)$ of the respondents work in private companies, $3(9.4 \%)$ respondents are self-employed, $10(31.2 \%)$ of respondents are jobless, while $6(18.8 \%)$ respondents are students. About the level of education, 1 $(3.1 \%)$ of the respondents are not schooling, $6(18.8 \%)$ of respondents manage to learn at the primary school, $16(50 \%)$ of the respondents manage to learn at the secondary school and $9(28.1 \%)$ of respondents to manage to study at the 
college or university.

\section{B. Syncretic Practices That Have the Highest Propensity among Respondents}

Based on the statistics in Table I, it obviously shows that cleaning the graves during the month of Shaaban and holding Mourn Feast at the day of 3, 7, 40 and 100 of the death of Kedayan people considered have the highest propensity among this community in which the score for both are $100 \%$.

TABLE I: THE FREQUENCY OF INTENTION TO PERFORM THE SYNCRETIC PRACTICES

\begin{tabular}{|l|l|l|l|}
\hline No & Syncretic practices & Disagree & Agree \\
\hline 1 & Langir ritual bath & $56.2 \%$ & $43.7 \%$ \\
\hline 2 & Incantations for healing & $59.4 \%$ & $40.6 \%$ \\
\hline 3 & Ritual before building the house & $21.9 \%$ & $78.2 \%$ \\
\hline 4 & Hanging the placenta & $25 \%$ & $75 \%$ \\
\hline 5 & Hunting tips and incantations & $9.4 \%$ & $90.6 \%$ \\
\hline 6 & $\begin{array}{l}\text { Cleaning the graves during the } \\
\text { month of Shaaban }\end{array}$ & $0 \%$ & $100 \%$ \\
\hline 7 & $\begin{array}{l}\text { Mourn Feast at the end of } \\
\text { Ramadhan month }\end{array}$ & $6.2 \%$ & $93.7 \%$ \\
\hline 8 & $\begin{array}{l}\text { Mourn Feast for 3 Fridays } \\
\text { continuously after the death }\end{array}$ & $9.3 \%$ & $90.7 \%$ \\
\hline 9 & $\begin{array}{l}\text { Mourn Feast at the day of 3, 7, 40 } \\
\text { and 100 of the death }\end{array}$ & $0 \%$ & $100 \%$ \\
\hline
\end{tabular}

\section{The Difference in the Individual Educational Level} towards their Attitudes and Intention of Performing the Syncretic Culture

This section will identify whether there are differences in attitudes towards syncretic practices and intentions to perform them from different educational levels of respondents using Kruskal-Wallis test.

Table II indicates the differences between attitudes towards syncretic culture with different educational levels statistically significant with the score of 0.017 . This difference is statistically significant at the $5 \%$ level (p-value<0.05).

Table III indicates that there is no significant difference between the intentions to practice syncretic culture with different levels of education with the score 0.095 .

The data indicates that although there are significant differences between the individual educational levels and their attitudes towards syncretic practices, by contrast, there is no significant difference between the individual educational levels and their intentions to perform syncretic traditions. This happens due to other factors that influence people's behavior to perform their traditions such as subjective norms, and perceived behavioral control rather than individual attitude alone.

TABLE II: THE KRUSKAL-WALLIS TEST RESULTS ON DIFFERENCES BETWEEN ATTITUDES TOWARDS TRADITION AND LEVEL OF EDUCATION

\begin{tabular}{|c|c|c|c|}
\hline \multicolumn{2}{|c|}{ Level of education } & $N$ & Mean Rank \\
\hline \multirow[t]{5}{*}{ Mean_A } & Not schooling & 1 & 32.00 \\
\hline & Primary School & 6 & 23.67 \\
\hline & $\begin{array}{l}\text { Secondary } \\
\text { School }\end{array}$ & 16 & 16.31 \\
\hline & $\begin{array}{l}\text { College / } \\
\text { University }\end{array}$ & 9 & 10.33 \\
\hline & Total & 32 & \\
\hline & Mean_A & & \\
\hline Chi-Square & 10.159 & & \\
\hline df & 3 & & \\
\hline Asymp. Sig. & .017 & & \\
\hline
\end{tabular}

TABLE III: THE KRUSKAL-WALLIS TEST RESULTS ON DIFFERENCES BETWEEN INTENTION TO PERFORM TRADITIONS AND LEVEL OF EDUCATION

\begin{tabular}{|c|c|c|c|}
\hline \multicolumn{2}{|c|}{ Level of education } & $N$ & Mean Rank \\
\hline \multirow[t]{6}{*}{ Mean_D } & Not schooling & 1 & 32.00 \\
\hline & Primary School & 6 & 21.25 \\
\hline & $\begin{array}{l}\text { Secondary } \\
\text { School }\end{array}$ & 16 & 16.28 \\
\hline & $\begin{array}{l}\text { College / } \\
\text { University }\end{array}$ & 9 & 12.00 \\
\hline & Total & 32 & \\
\hline & Mean_D & & \\
\hline Chi-Square & 6.375 & & \\
\hline df & 5 & & \\
\hline Asymp. Sig. & .095 & & \\
\hline
\end{tabular}

D. The Correlation between Attitudes, Subjective Norms, and Perceived Behavioral Control with the Intentions to Perform Their Syncretic Traditions

This section will find out the correlation between attitudes, subjective norms and perceived behavioral control with the intentions to perform the syncretic traditions.

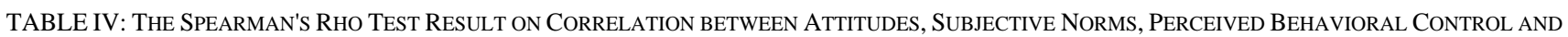
INTENTIONS TO PERFORM TRADITIONS

\begin{tabular}{|c|c|c|c|c|c|c|}
\hline & & & mean $\mathrm{A}$ & mean_B & mean_C & mean_D \\
\hline \multirow[t]{12}{*}{ Spearman's rho } & \multirow[t]{3}{*}{ mean $\mathrm{A}$} & Correlation Coefficient & 1.000 & $0.876^{* * *}$ & $0.378^{*}$ & $0.788^{* * *}$ \\
\hline & & Sig. (2-tailed) & 0 & 0.000 & 0.033 & 0.000 \\
\hline & & $\mathrm{N}$ & 32 & 32 & 32 & 32 \\
\hline & \multirow[t]{3}{*}{ mean B } & Correlation Coefficient & $0.876^{* *}$ & 1.000 & $0.478^{* *}$ & $0.796^{* *}$ \\
\hline & & Sig. (2-tailed) & 0.000 & 0 & 0.006 & 0.000 \\
\hline & & $\mathrm{N}$ & 32 & 32 & 32 & 32 \\
\hline & \multirow[t]{3}{*}{ mean $\mathrm{C}$} & Correlation Coefficient & $0.378^{*}$ & $0.478^{* *}$ & 1.000 & $0.623^{* *}$ \\
\hline & & Sig. (2-tailed) & 0.033 & 0.006 & 0 & 0.000 \\
\hline & & $\mathrm{N}$ & 32 & 32 & 32 & 32 \\
\hline & \multirow[t]{3}{*}{ mean D } & Correlation Coefficient & $0.788^{* *}$ & $0.796^{* *}$ & $0.623^{* *}$ & 1.000 \\
\hline & & Sig. (2-tailed) & 0.000 & 0.000 & 0.000 & 0 \\
\hline & & $\mathrm{N}$ & 32 & 32 & 32 & 32 \\
\hline
\end{tabular}

Table IV indicates the correlation coefficient between subjective norms and the intentions to perform the traditions is significant, and at +0.796 , is the strongest, followed by between attitudes of individuals and the intentions to perform the traditions $(+0.788)$. The correlation between perceived behavioral control and intentions to perform the traditions is 
also significant and positive but moderate with the score at +0.623 .

\section{CONCLUSION}

Overall, these preliminary findings indicate that the intentions of Kedayan people to perform their culture which are associated with syncretism in nature are considered high. However, there are differences between individual educational levels and intentions to perform the syncretic traditions. Thus, the education among the society should be put into consideration to ensure that the community avoids the element of syncretism that may conflict with the Islamic faith. It is not meant that all the syncretic practices should be eliminated but, the one which are contrary to the Islamic faith should be reconciled in accordance to the faith.

\section{ACKNOWLEDGMENT}

Author thanks Kedayan people in Sipitang for their commitment and support in this research. A special thanks is dedicated to Haji Daim bin Bakar.

\section{REFERENCES}

[1] W. L. Reese, Dictionary of Philosophy and Religion, New Jersey: Humanities Press Inc., 1980, pp. 564.

[2] Plutarch, Moralia (trans.), Frank Cole Babbitt, London: William Heinemann Ltd., 1960, vol. I, pp. ix-xxx.

[3] P. P. Wiener (Ed), Dictionary of the History of Ideas, New York: Charles Scribner's Sons, 1973, vol. 1, pp. 43.

[4] S. L. Budin, "A Reconsideration of the Aphrodite-Ashtart Syncretism," Numen: International Review for the History of Religions, vol. 51, Issue. 2, pp. 95-145, 2004.

[5] H. R. Willoughby, Pagan Regeneration: A Study of Mystery Initiations in the Graeco-Roman World, Chicago: The University of Chicago Press, 1929, pp. 8.

[6] J. Webster and C. Gosden, "Necessary comparisons: A post-colonial approach to religious syncretism in the Roman provinces," World Archaeology, vol. 28, Issue. 3, pp. 324-338, 1997.

[7] A. M. C, Wilson, Diderot, Oxford: Oxford University Press, 1972, pp.vii, $75 \& 712$.

[8] J. Hastings (Ed), Encylopaedia of Religion and Ethics, Edinburgh, 1921, vol. XII, pp. 156.

[9] A. T. Levenson, "Syncretism and Surrogacy in Modern Times: Two Models of Assimilation," Shofar: An Interdisciplinary Journal of Jewish Studies, vol. 30, Issue. 1, pp.17-30, 2011.

[10] R. Baird, Category Formation and the History of Religion, Hague: Mouton, 1971, pp.146.

[11] P. Schineller, "Inculturation and syncretism: What is the real issue?" International Bulletin of Missionary Research, vol. 16, Issue. 2, pp. 50, 1992.

[12] S. Engler, "Umbanda and Hybridity," Numen: International Review for the History of Religions, vol. 56, Issue. 5, 2009, pp. 545-577.

[13] E. Zehner, "Orthodox hybridities: Anti-syncretism and localization in the evangelical Christianity of Thailand," Anthropological Quarterly, vol. 78, Issue. 3, pp. 585-617, 2005.

[14] S. E. Kraft, "'To mix or not to mix': syncretism/anti-syncretism in the history if theosophy," Numen: International Review for the History of Religions, vol. 49, Issue. 2, pp. 142, 2002.

[15] R. J. Schreiter, "Defining syncretism: An interim report," International Bulletin of Missionary Research, vol. 17, Issue. 2, pp. 50, 1993.

[16] L. H. Martin, "Of religious syncretism, comparative religion and spiritual quests," Method and Theory in the Study of Religion, vol. 12, Issue. 1/2, 2000, pp. 277.

[17] C. Colpe, "Syncretism," in The Encyclopaedia of Religion, New York and London: Macmillan, 1987, vol. 14, pp. 218-227.

[18] M. Pye, "Syncretism versus synthesis," Method and Theory of Study of Religion, vol. 6, pp. 217-229, 1994.

[19] P. Schwadel, "Jewish teenagers' syncretism," Review of Religious Research, vol. 51, Issue. 3, pp. 324-332, 2010.
[20] A. Sidik, The Mystic of Borneo: Kadayan, Kota Kinabalu: Borneo Publishers, 2007, pp. 124.

[21] N. Baharom, Kamus Dewan $4^{\text {th }}$ edition, Kuala Lumpur: Dewan Bahasa dan Pustaka, 2005, pp. 702.

[22] E. Parnell, "The Names Kadayan, Dayak and Tanjong Datu," The Sarawak Museum Journal, pp. 150-151, 1911.

[23] A. R. Maxwell, "On the various spellings of the word 'Kadayan'," Brunei Museum Journal, vol. 1, no. 1, pp. 87-103, 1970.

[24] S. Bagol, "Adat Istiadat dan Kebudayaan Suku Kaum Kedayan: Satu Tinjauan di Daerah Sipitang,” B. A. Dissertation, Universiti Pertanian Malaysia, 1994.

[25] A. Sidik, The Mystic of Borneo: Kadayan, Kota Kinabalu: Borneo Publishers, 2007, pp. 9.

[26] C. Sather and H. Solhee, "Kampung Selanyau: Social and Economic Organization of Kedayan Rice-Growing Village," Sarawak Museum Journal, vol. XXII, no. 43, pp. 249-226, 1974.

[27] J. Tani, Sosioekonomi Komuniti Kadayan, Kuala Lumpur: Dewan Bahasa dan Pustaka, 1991, pp. 15.

[28] T. Harrison, "Kedayan Raft," Brunei Museum Journal, vol. 2, no. 1, pp. 52-59, 1970

[29] L. Jaafar, "Menuba Di-Kalangan Masharakat Kedayan," BAHANA, Brunei: Dewan Bahasa Dan Pustaka Brunei, vol 16, no. 34, pp. 49-53, 1981.

[30] P. M. Sharifuddin, "Makan Tahun: The annual feast of the Kedayans," Brunei Museum Journal, vol. 2, no. 1, pp. 61-66, 1970.

[31] A. Ahmad, "Tradisi Makan Tahun Dalam Masyarakat Kedayan," Beriga, vol. 15, pp. 11-16, 1987.

[32] M. S. Salleh, "Praktik Budaya Dan Status: Kajian Kes Kedayan Sarawak," Persidangan Agama Dan Masyarakat, Universiti Malaysia Sabah, Kota Kinabalu, 2012.

[33] M. M. Magiman, "Ritual 'Makan Tahun' masyarakat Kadayan di Kg. Selanyau Daerah Kecil Berkenu, Sarawak," Ph.D. thesis, Universiti Malaya, Kuala Lumpur, 2012.

[34] I. Ajzen, "From intentions to actions: A theory of planned behavior," in J. Kuhl and J. Beckman (eds), Action-Control: From Cognition to Behavior, Heidelberg: Springer, pp. 11-39, 1985.

[35] P. D. Leedy, Practical Research: Planning and Design, 6th ed. Merrill, pp. 268-270, 1997.

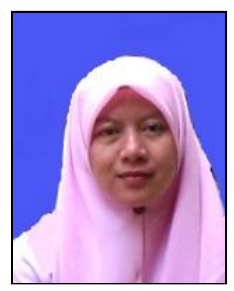

Ros Aiza Mohd Mokhtar was born in Kuala Lipis, Pahang, Malaysia in 1974-10-10. She obtained her first degree from International Islamic University of Malaysia (IIUM), Selangor, Malaysia, in the field of Islamic Revealed Knowledge and Heritage in 1998. Later, she earned a Master degree in Civilization Studies from University of Malaya (UM), Kuala Lumpur, Malaysia in a year of 2004. Currently she is doing a $\mathrm{PhD}$ program in religious study at University of Malaya. Her PhD program is sponsored by Malaysia Ministry of Higher Education.

She works as a lecturer at Universiti Malaysia Sabah, Sabah, Malaysia since 2007 onwards. Used to be a teacher and lecturer in several schools and institutions. Among her latest publications are Pulau Mabul: Dulu, Kini dan Masa Depan (Kota Kinabalu: Universiti Malaysia Sabah, 2012), Kemahiran Insaniah Dalam Pembelajaran Kursus Tamadun Islam dan Tamadun Asia: Perspektif Pelajar Universiti Malaysia Sabah (Kota Kinabalu: Universiti Malaysia Sabah, 2011), Adat dan Ritual Kematian di Sabah (Kota Kinabalu: Universiti Malaysia Sabah, 2010). She currently doing a research on syncretism among Kedayan people. Among her previous reseraches are on belief system of Sulu people in Mabul, Sabah, Malaysia, implementation and implication of Civilization Subject at University level in Malaysia.

Ros Aiza Mohd Mokhtar (Ph.D. candidate). Commitee member of UMS Association of Mixed-Methods Researchers (UMAR), commitee member of Malaysia Higher Education Institution session 2010-2012 for the Islamic and Asian Civilization course. She also served as editor for MANU Journal vol. 14 (2009), 15 (2010), 16 (2011), Pusat Penataran Ilmu dan Bahasa Universiti Malaysia Sabah.

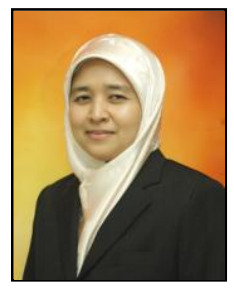

Che Zarrina Sa'ari was born in Kuala Terengganu, Terengganu, Malaysia in 1967-01-02. She obtained her first degree from University of Malaya (UM), Kuala Lumpur, Malaysia, in the field of Usuluddin in 1991. Later, she earned a Master degree in Usuluddin from University of Malaya (UM), Kuala Lumpur, Malaysia in a year of 1993. She graduated her Ph.D. program in Usuluddin at Edinburgh University, United Kingdom in 1998. 
She works at Universiti of Malaya Kuala Lumpur since 1999 onwards. Her current position is associate professor. Among her latest publications are Konsep al-Tanzih Imam al-Qushayri (Kuala Lumpur: Universiti Malaya, 2013), Kaedah Psikoterapi Islam Berasaskan Konsep Maqamat Abu Talib al-Makki (Kuala Lumpur: Dewan Bahasa dan Pustaka, 2012), Monograph Series Centre For Civilisational Dialogue, Ostad Elahi On Sprituality in Everyday Life by James W. Morris (Kuala Lumpur: University of Malaya, 2010). Her area of reserach are Sufism, Islamic Psychology, Islamic Psychotherapy, Islamic Thought, Islamic Ethic, Comparative Religion and Aqidah. She currently doing a research on Faktor Psiko-spiritual Remaja Lari dari Rumah: Kajian Teks Tarbiyah al-Awlad dan Kes Studi di Beberapa Buah Pusat Perlindungan Remaja di Malaysia. Among her previous reseraches are Ahmadiyyah Idrisiyyah Order in Malay Archipelago and Its Relation With Middle East from Historical, Teachings and Practices Aspects:
An Evaluation, Pola Rawatan Penyalahgunaan Dadah Perbandingan Antara Psikoterapi Islam Dengan Psikoterapi Alternatif and Sufistic Practice and Its Application in Modern Life in Indonesia: A Study on Syadziliyah Order at Bandar Pekalongan, Central Java.

Dr. Che Zarrina Sa'ari. Among her membership are The General Council of The University of Edinburg, British Society for Middle Eastern Studies (BRIMES). Being awarded and recognised such as the Most Informative Project, University of Malaya Research, Invention \& Innovation Expo, University of Malaya (2010), Silver Medal, University of Malaya Research, Invention Expo, University of Malaya (2009), Award of Publication (Royalty more than RM1000), University of Malaya (2008), Postdoctorate Fellowship, University of Edinburgh (2010), Research Fellow at University of Leiden, Netherlands, University of Malaya (Sabbatical leave)/ University of Leiden (2004). 